\title{
Attitudes toward WebCT and Learning: An Omani Perspective
}

\author{
Syed Jafar Naqvi and Manzur Ali Ajiz \\ Sultan Qaboos University, Al-Khod, Sultanate of Oman
}

cce3249@squ.edu.om manzur@squ.edu.om

\begin{abstract}
This study investigated the students attitudes toward the use of World Wide Web Course Tools (WebCT) and its influence on learning taking a course Introduction to Computers in Business offered at the College of Commerce and Economics in Sultan Qaboos University in Oman. Sultan Qaboos University is a co-educational institution where in most computer classes the male and female students are equally distributed. Omani society is a segregated society where male and female students have some how different life style and have different attitudes towards learning Information Technology.

This research is exploring the difference if any of their attitudes toward WebCT, where WebCT was introduced in their "Introduction to Computers in Business" course as a supplementary learning tool. The finding showed that though male students have little more exposure of WebCT at the beginning of the course than the females, but towards the end of the course the male and female students have appreciated almost equally the importance and the use of WebCT as it is easily accessible from any Internet enabled location and at any time in addition it helps them in better understanding and learning the course material.
\end{abstract}

Keywords: WebCT, learning, Information Technology, student attitudes

\section{Introduction}

Oman, is a developing nation striving to improve her education through their national reforms. Sultan Qaboos University is the only national university in the country, serving to more than 10000 male and female students at a time. Recently the Center for Education Technology (CET), of Sultan Qaboos University has provided access to WebCT to all colleges in the University. At the College of Commerce and Economics the instructor has introduced WebCT for students to have access the digital contents of the Introduction to Computers in Business course along with the traditional course teaching.

The moving from traditional learning to using digital learning environment like WebCT may

Material published as part of this publication, either on-line or in print, is copyrighted by the Informing Science Institute. Permission to make digital or paper copy of part or all of these works for personal or classroom use is granted without fee provided that the copies are not made or distributed for profit or commercial advantage AND that copies 1) bear this notice in full and 2) give the full citation on the first page. It is permissible to abstract these works so long as credit is given. To copy in all other cases or to republish or to post on a server or to redistribute to lists requires specific permission and payment of a fee. Contact Publisher@InformingScience.org to request redistribution permission. have some implications on students' attitudes. This study investigating their overall attitudes toward WebCT based on gender differences when taking "Introduction to Computers in Business” course.

One of the most apparent trends affecting education is the advancement of technology. Infrastructures are growing stronger as computers double in speed while decreasing in cost, and high-speed 
network connections continue to expand. Computer, fax, picture phone, duplication, and other modalities are merging and becoming available at ever cheaper prices (Cetron, 2003).

"New technology will transform higher education as we know it today" (Oblinger, Barone, \& Hawkins, 2001), one example being the changes caused by broader use of e-texts and PDAs (Chick et al., 2002). By the year 2012, schools and colleges will routinely use "computerized teaching programs and interactive television lectures and seminars, as well as traditional methods” (World Future Society, 2003). Videoconferencing and other technologies will also help enrich distance media and provide many benefits for face-to-face instruction.

Dunn (2000) projected changes in higher education's landscape over the next 20 years. "The number of degree-granting institutions will continue to grow, while the number of traditional campuses will decline.”

The current technology may continue to increase the options available for distributing distance education to more people in a scalable fashion, especially if it is accompanied by technological fluency. Several universities have started offering courses using WebCT, Moodle, Blackboard or similar packages mainly for their distance education programs. Sultan Qaboos University has recently started using WebCT as a supportive tool to its traditional teaching.

\section{What is WebCT?}

WebCT is a course management system that enables the delivery of online education. With a complete set of teaching and learning tools for course development, course delivery, and course management, WebCT provides a system for student learning and an efficient solution for faculty of all experience levels (Williams, 2003). It allows educators to design the appearance of course pages, it provides a set of educational tools that can easily be incorporated into any course, and it provides a set of administrative tools that assist the educator in the task of course administration (Goldberg, Salari, \& Swoboda, 1996).

The advantages of WebCT include a simple interface that can be accessed from anywhere a network-connected computer is available. While this is important for all users of WebCT who enjoy time and location independent access to their learning resource (Williams, 2003).

\section{Purpose of the Study}

The purpose of this study was to explore attitudes and gender differences toward WebCT and its effects on understanding and learning in the course "Introduction to Computers in Business" offered at the Sultan Qaboos University where WebCT is recently introduced.

\section{Methodology}

The sample for this study consisted of seventy one students enrolled for the course where male students were 37 (52\%) and female were 34 (48\%). These students had similar educational background and having no or little initial IT skills. All students were allowed to have access to the course on campus or else where with a uniform access procedure.

A questionnaire was developed for this study. It comprised of fourteen questions designed covering four major domains related to accessing WebCT, Attitudes toward WebCT, WebCT helps in acquiring IT skills and WebCT in teaching. The questionnaire was administered in the similar way to all students in the course. There were two stages for data collection Prior and After. The Prior data collection point was at the beginning of the course, while After data collection point was at the end of the course. The course lasted for one semester of sixteen weeks. 
Responses to each item were based on Likert scale ranging from 1 to 5 , where $1=$ Strongly Disagree, 2 = Disagree, 3 = Uncertain (never used WebCT before), 4 = Agree, 5 = Strongly Agree, as shown in Appendix 1.

The same course outline, syllabus, data collection and processing tools were used in the study. The responses-means prior to the course and after the course were compared to see if there was any marked difference between male and female students attitudes toward WebCT and its effects on learning the course material.

Simple analysis of the data was done by comparing the means to assess the size of change in the male and female students. The results of these comparisons were incorporated to examine the effects on issues like students accessibility to WebCT, attitudes toward WebCT, learning and understanding the course material.

\section{Results and Findings}

\section{WebCT Accessibility}

The WebCT accessibility was found to be low for both male and female students prior to the course. In fact it is lower for female students $(\mathrm{M}=2.65)$ as compared to the male students $(\mathrm{M}=3.20)$. It might be that only few students had taken a course prior to this requiring to use WebCT while others had not used it before.

But after the enrollment in the course each student was given user account to access the WebCT. Most students responded very high as the mean response for male students were $(\mathrm{M}=4.48)$ and female students were $(\mathrm{M}=4.45)$. There is no significant difference between male and female students on issue of WebCT accessibility during or After the course as compared Prior to the course.

The means of the survey of both the groups at Prior and After stages along with the change from Prior to After are tabulated in Table 1 and the graphical representations of Prior vs. Prior and After vs. After is shown in Figure 1 and Figure 2 correspondingly, showing at After stage both male or female students had better access to WebCT.

Table 1. Accessing WebCT

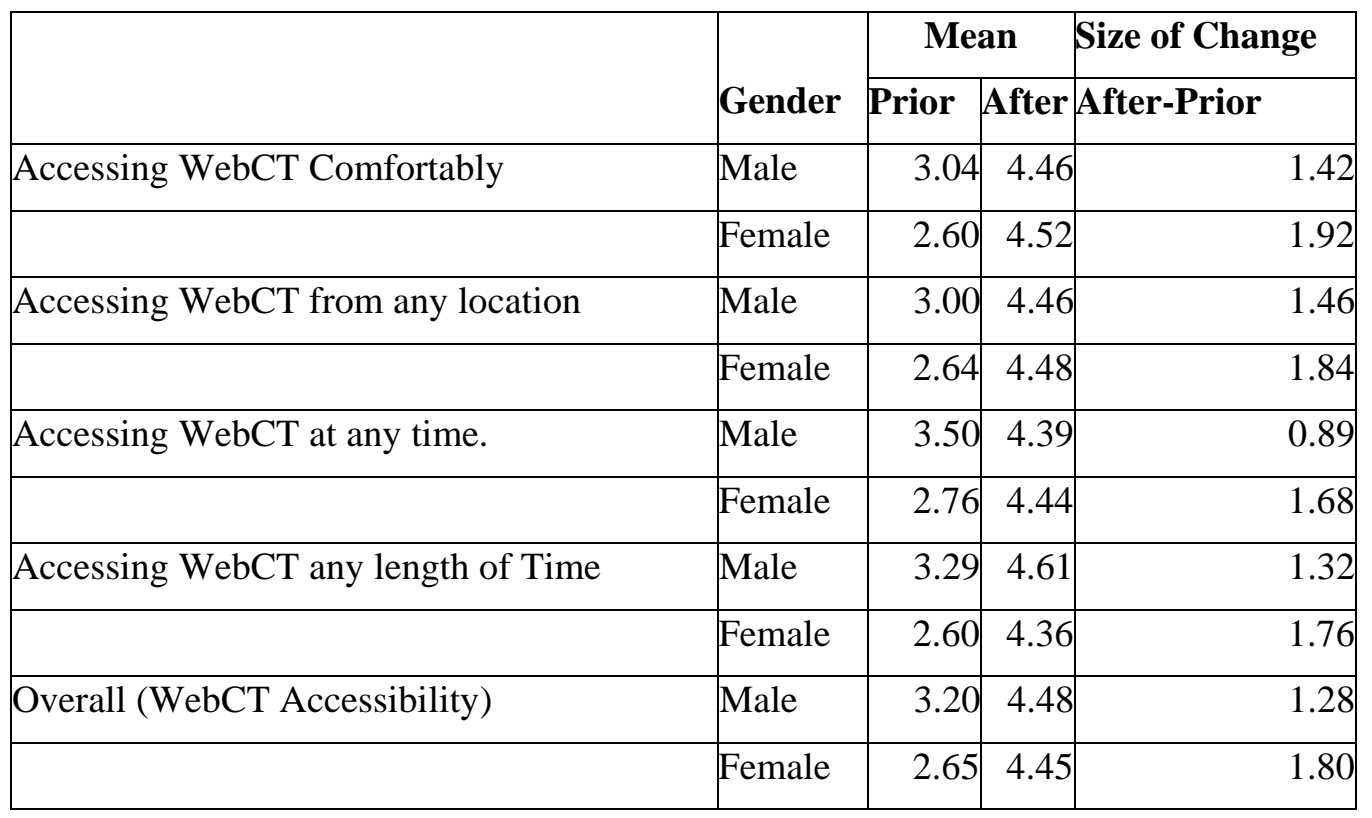




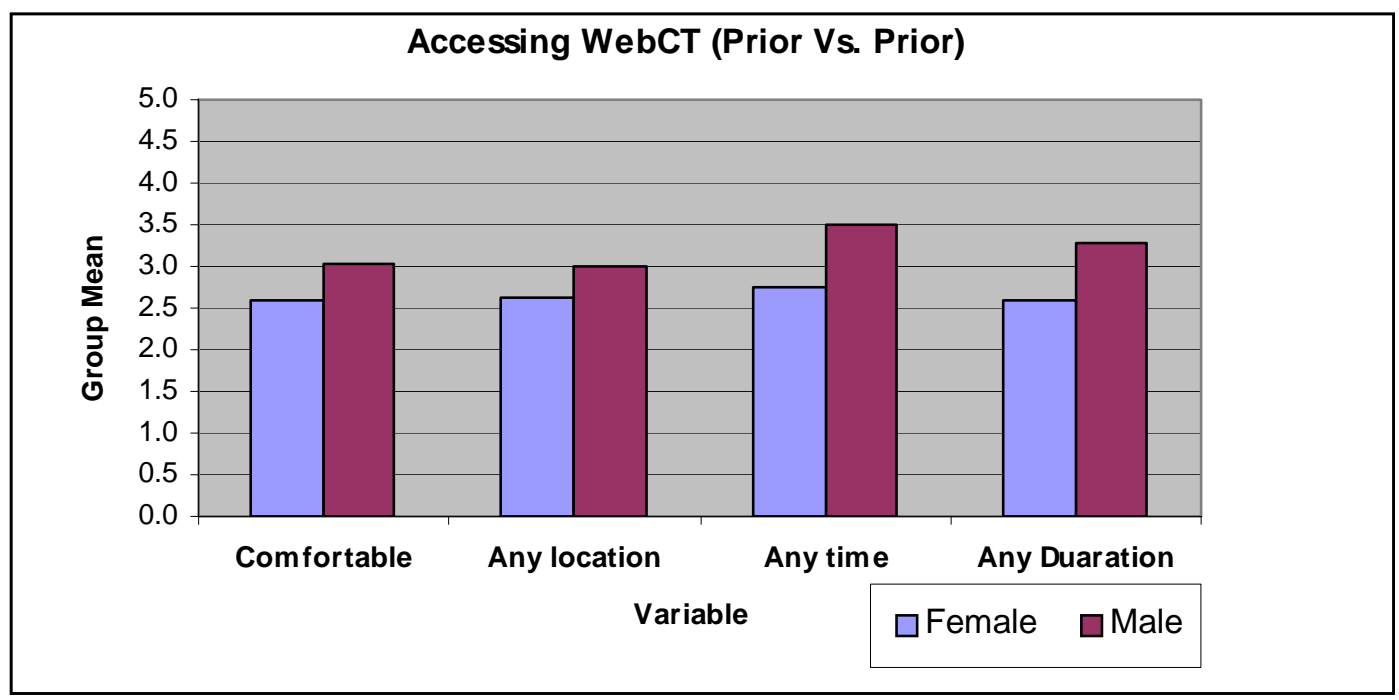

Figure 1: Accessibility of WebCT (Prior Vs. Prior)

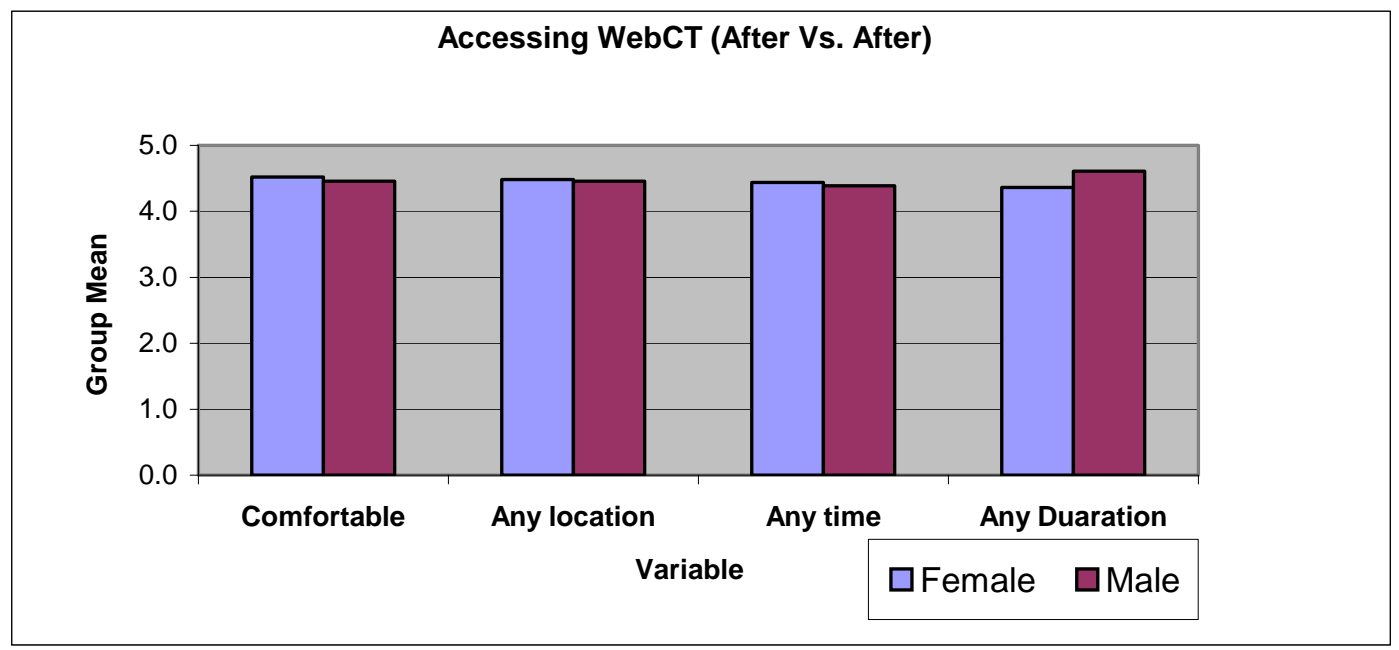

Figure 2: Accessibility of WebCT (After Vs. After)

\section{Attitudes toward WebCT}

The overall attitudes toward the WebCT was found to be less positive or like neutral for all students prior to the course as it could be seen by comparing the means for females $(\mathrm{M}=2.70)$ and males $(M=3.33)$. This could be because of lack of access to WebCT by all students especially the females at the beginning of the course.

But at the end of the course, when the WebCT was more easily accessible to all students their attitudes toward the WebCT had improved. When considering the size of change from Prior to After, both groups have indicated a significant difference between the attitudes at the After stage versus the Prior stage of the course. However, this change is more among female students as compared to male students, might be because of the lack of accessibility of WebCT.

In general, both male and female students have indicated more positive attitudes toward WebCT when surveyed at the After stage of the course. This is shown in Table 2 and graphically presented in Figure 3 and Figure 4. It is interesting to note that the same pattern is shown with 
WebCT accessibility. It appears that those students who got more accessibility of WebCT had more positive attitudes toward WebCT.

Table 2. Attitudes toward WebCT

\begin{tabular}{|l|l|r|r|r|}
\hline \multirow{2}{*}{ Dependent Variables } & & \multicolumn{2}{|c|}{ Mean } & \multicolumn{2}{l|}{ Size of Change } \\
\cline { 4 - 6 } & \multirow{2}{*}{ Gender } & Prior & After & After-Prior \\
\hline & Male & 3.29 & 4.54 & 1.25 \\
\hline Feel Friendly using WebCT & Female & 2.84 & 4.52 & 1.68 \\
\hline & Male & 3.21 & 3.93 & 0.72 \\
\hline Feel relaxed with WebCT Interaction & Female & 2.96 & 4.52 & 1.56 \\
\hline & Male & 3.43 & 4.43 & 1.00 \\
\hline Feel WebCT is Important & Female & 2.96 & 4.68 & 1.72 \\
\hline & Male & 3.39 & 4.57 & 1.18 \\
\hline Overall(Attitude towards WebCT) & Female & 3.04 & 4.64 & 1.60 \\
\hline & Male & 3.33 & 4.37 & 1.04 \\
\hline & Female & 2.96 & 4.59 & 1.63 \\
\hline
\end{tabular}

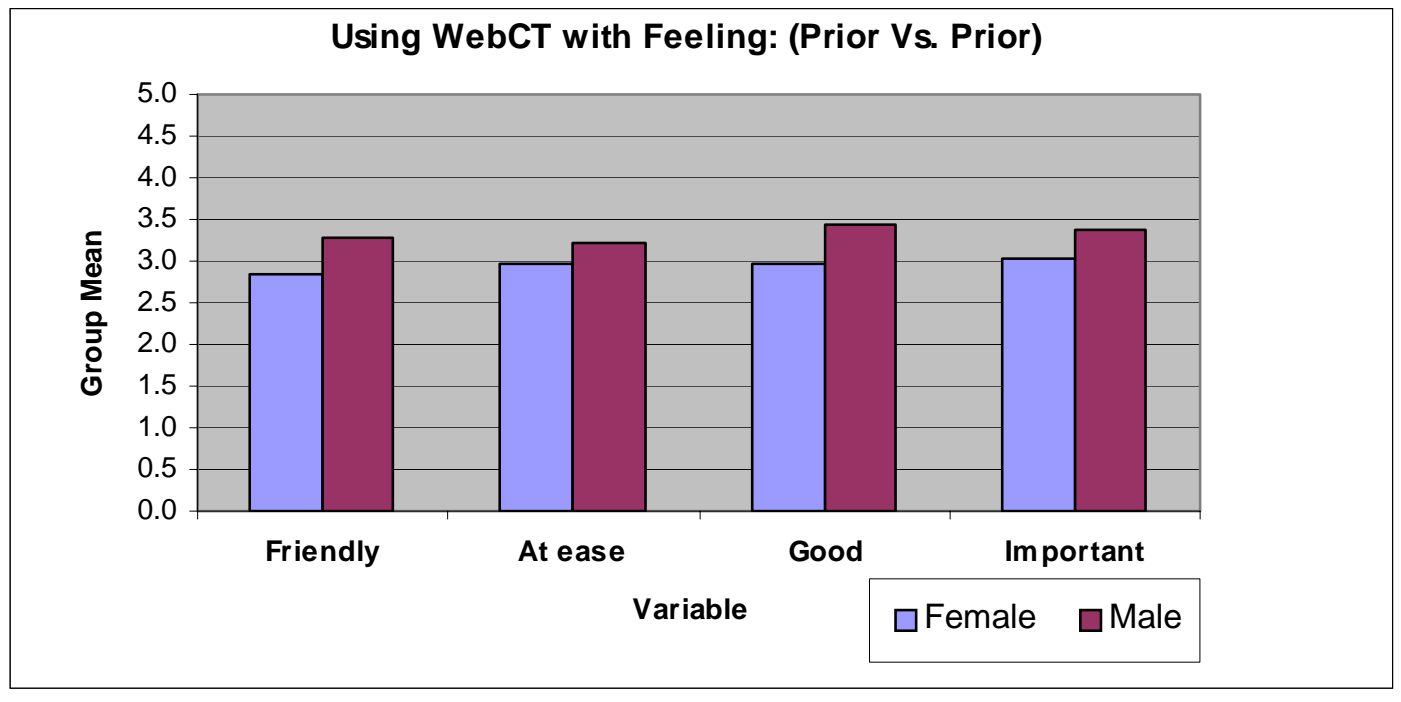

Figure 3: Attitudes towards WebCT (Prior Vs. Prior) 


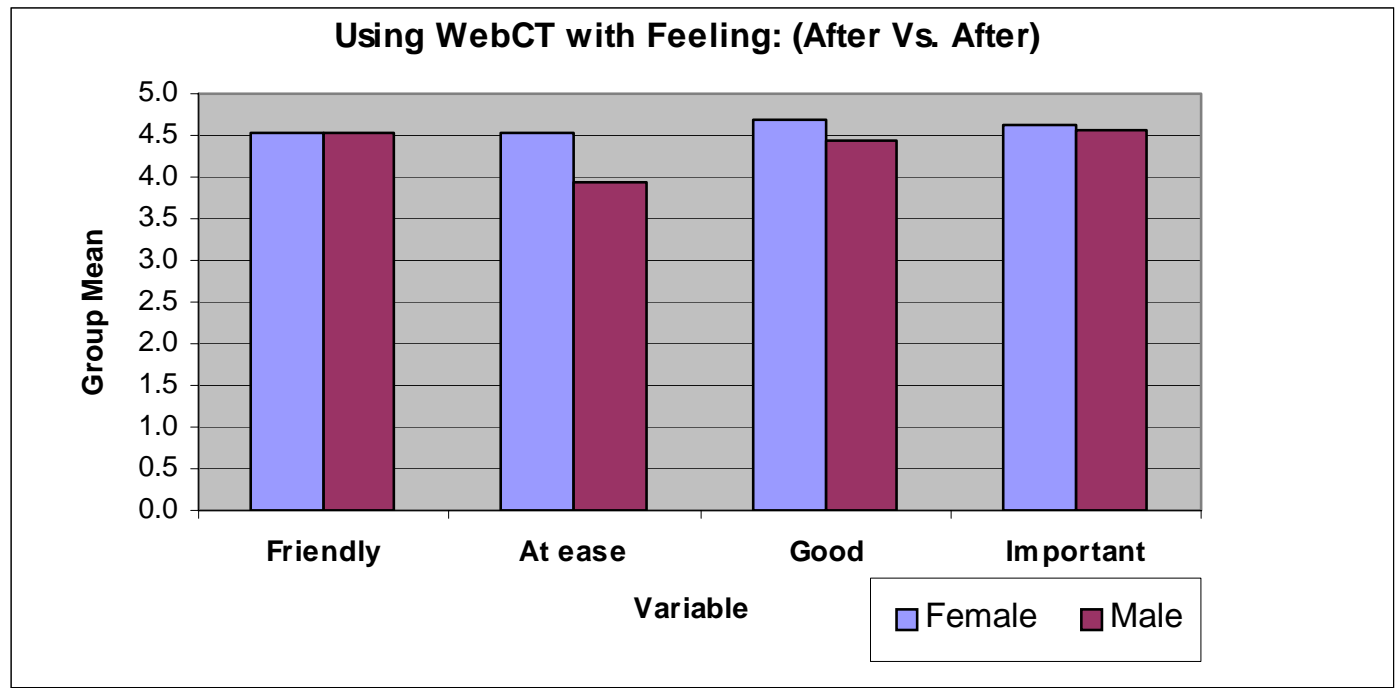

Figure 4: Attitudes towards WebCT (After Vs. After)

\section{Learning through WebCT}

The overall perception of male and female students towards the WebCT as a tool for learning was poor Prior to the course. When comparing the overall mean responses given by male students $(\mathrm{M}=2.94)$ while for female students was $(\mathrm{M}=2.92)$, showing no significant difference.

But when asked at After stage of the course both male and female students have really appreciated the effects of WebCT on their learning. The students got more accessibility of WebCT using it with more positive attitudes. The overall mean responses regarding the effects of the WebCT on their learning, the overall male students mean was $(M=4.53)$ while for female students was $(\mathrm{M}=4.84)$ showing very high but similar responses. But when the size of change from Prior to After were compared, indicated a highly significant difference as shown in Table 3 and graphically presented in Figure 5 and Figure 6.

All students regardless of gender believed that WebCT improved their learning, understanding and exam preparation.

Table 3. WebCT helps in the course with:

\begin{tabular}{|l|l|r|r|r|}
\hline & & \multicolumn{2}{|l|}{ Mean } & \multicolumn{2}{l|}{ Size of Change } \\
\cline { 3 - 6 } & Gender & Prior & After & After-Prior \\
\hline Better understanding & Male & 3.00 & 4.39 & 1.39 \\
\hline Better learning & Female & 2.72 & 4.88 & 2.16 \\
\hline & Male & 2.96 & 4.54 & 1.58 \\
\hline Better preparation for exams & Female & 3.04 & 4.80 & 1.76 \\
\hline & Male & 2.86 & 4.68 & 1.82 \\
\hline Overall(Helps in the course learning) & Male & 2.94 & 4.53 & 1.84 \\
\hline & Female & 3.00 & 4.84 & 1.59 \\
\hline
\end{tabular}




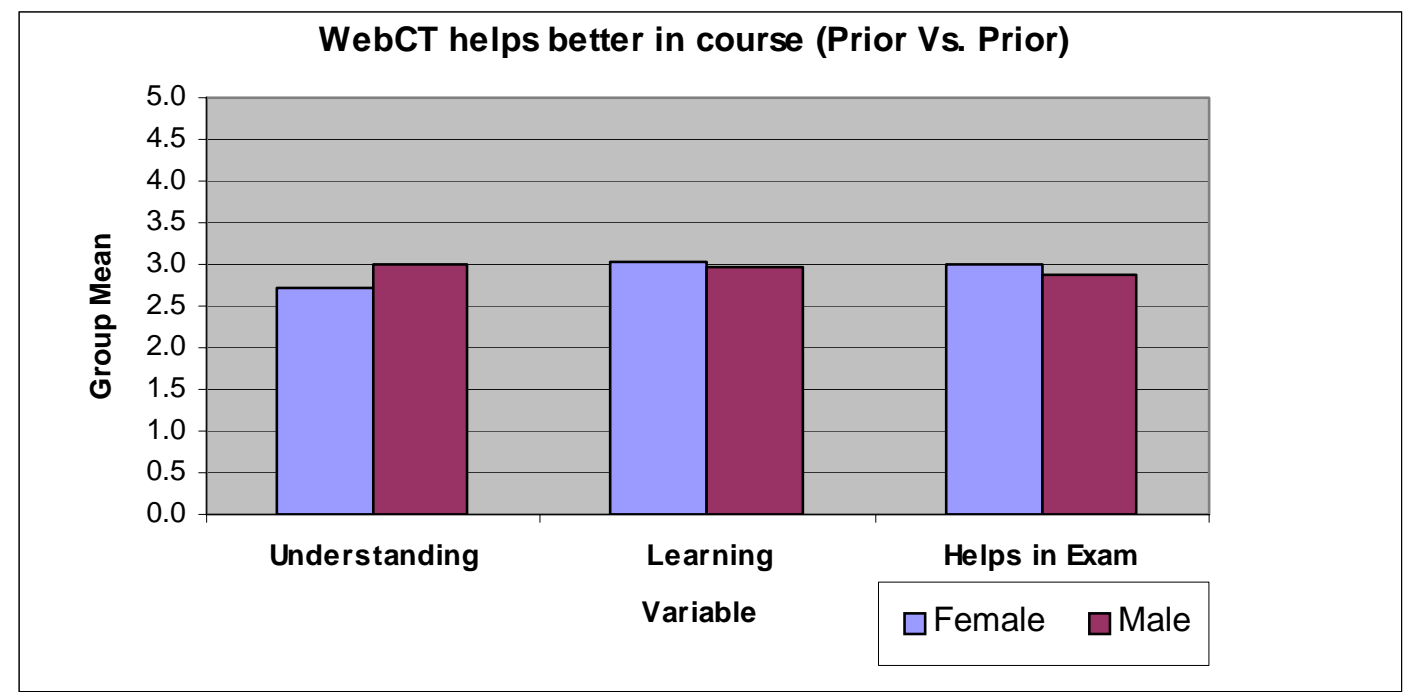

Figure 5: WebCT and Learning (Prior Vs. Prior)

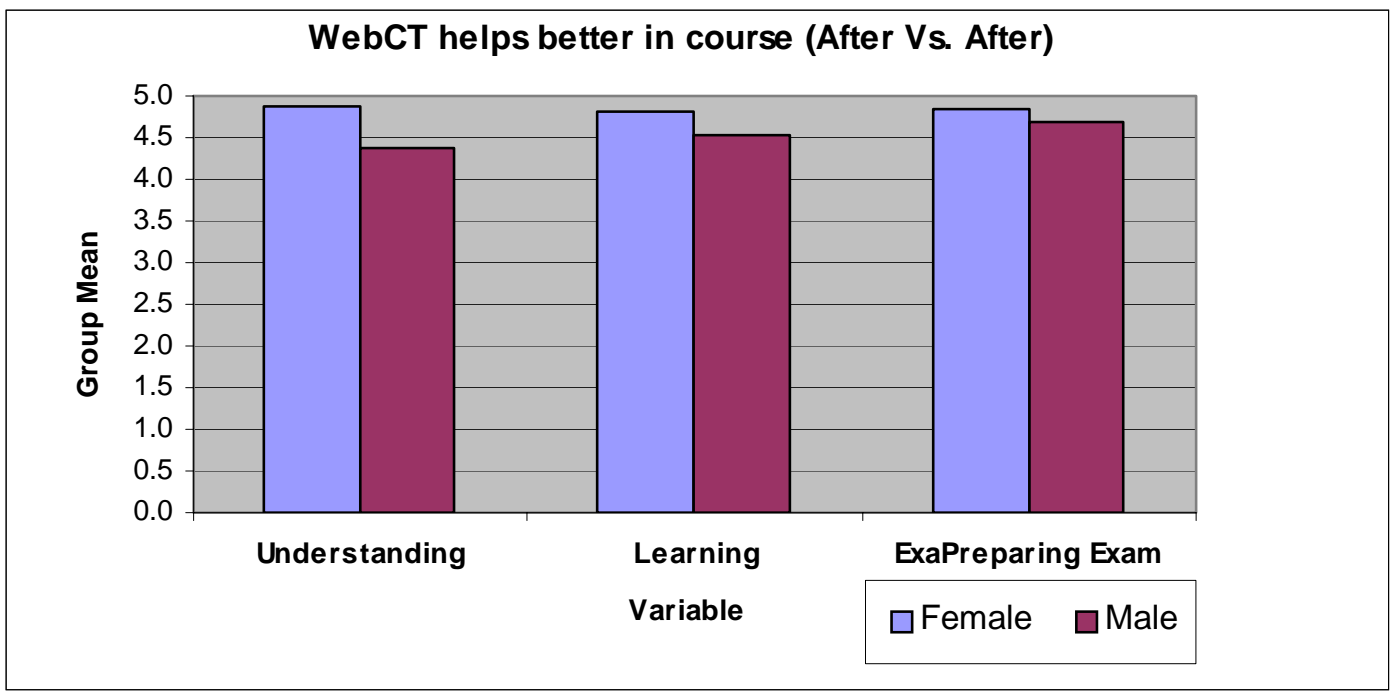

Figure 6: WebCT and Learning (After Vs. After)

\section{Conclusion}

The results of the survey showed that most students had little exposure to WebCT prior to the course and did not appreciate its benefits. After completing the course students expressed a more positive attitude towards WebCT. This positive change in their attitudes appears have contributed towards better understanding and learning the course material through WebCT as it was made easily accessible from any Internet enabled location at any time of the day for any duration.

In summary, those students who had access to WebCT had more positive attitude towards it and reported better understanding and learning of the course material (Figure 7).

The findings of this study are also in line with Koohang (1989), Hunt and Bohlin (1993), and Gressard and Loyd (1985), in that greater use of IT brings about more positive attitudes and hence greater confidence in the users. This enhanced confidence, in turn, results in more use, which may lead to even greater learning. 


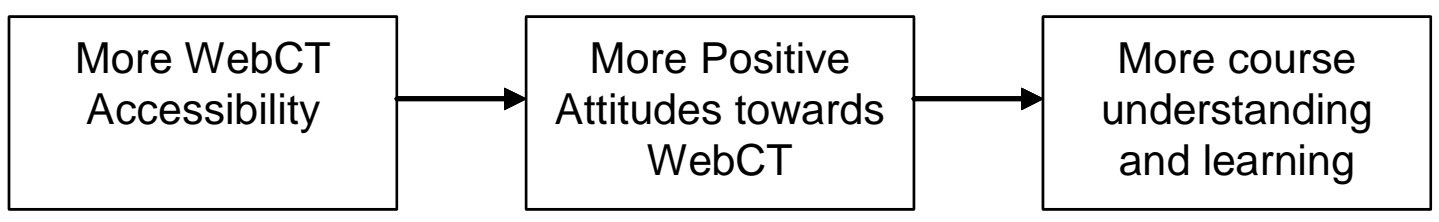

Figure 7: WebCT (accessibility, attitudes and learning)

With the increasing spread of the Internet and the proliferation of computing devices, technological literacy is becoming more vital. Distance education is becoming more widespread, especially online, and location independent, increasing the need for effective course-management systems and teaching strategies that utilize technology. The WebCT, Moodle or similar packages may continue play a major role influencing the students learning and meet students need and also overcome the funding challenges that traditional institutions could not offer.

\section{References}

Cetron, M. J., \& Daview, O. (2003). 50 trends shaping the future. Special Report Published by the World Future Society.

Chick, S., Day, R., Hook, R., Owston, R., Warkentin, J., Cooper, P. M., Hahn, J., \& Saundercook, J. (2002). Technology and student success in higher education: A research study on faculty perceptions of technology and student success. Toronto, Ontario McGraw-Hill Ryerson.

Dunn, S. (2000), The virtualizing of education. The Futurist, 34(2), 34-38.

Goldberg, M. W., Salari, S. \& Swoboda, P. (1996), World Wide Web Course Tool: An Environment for Building WWW-Based Courses, Computer Networks and ISDN Systems.

Gressard, C. P. \& Loyd, B. H. (1985). Validation studies of a new computer attitude scale. Paper presented at the Annual Meeting of the American Educational Research Association, Chicago.

Hunt, N. P. \& Bohlin, R. M. (1993). Teacher education students attitudes towards using computers. Journal of Research on Computing in Education, 25(4), 487-497.

Koohang, A. A. (1989), A study of attitudes toward computers: Anxiety, confidence, liking and perception of usefulness. Journal of Research on Computing in Education, 22(2), 137-50.

Oblinger, D., Barone, C.A., \& Hawkins, B.L. (2001). Distributed education and its challenges: An overview. American Council on Education (ACE). Retrieved June, 2003 from http://www.acenet.edu/bookstore/pdf/distributed-learning/distributed-learning-01.pdf

West, G.B. (1999). Teaching and technology in higher education: Changes and challenges. Adult Learning, 16-18.

Williams, P.E. (2003). Roles and competencies for distance education programs in higher education institutions. The American Journal of Distance Education, 17(1), 45-57.

The World Future Society. (2003). Emerging technologies and ground-floor investment opportunities. Special Report: Forecasts for the Next 25 Years. Bethesda, Maryland. 


\section{Appendix 1 \\ College of Commerce and Economics \\ Questionnaire form \\ Introduction to Computers in Business (INFS 1411)}

Spring, 2005

Please Tick

Dear Student:

\begin{tabular}{|l|l|}
\hline Male & Female \\
\hline & \\
\hline
\end{tabular}

The purpose of this form is to get your feedback regarding the course. Your input will help us in understanding and improving the course delivery process and will not at all affect the assessment of your work. Evaluate the following statements by selecting:

$1=$ Strongly Disagree $\quad 2=$ Disagree $\quad 3=$ Uncertain

$$
4=\text { Agree } \quad 5=\text { Strongly Agree }
$$

(Never used WebCT)

\section{Please circle your response;}

$$
\text { Before Course After Course }
$$

Thanks for your help

1. I access WebCT comfortably.

2. I access WebCT from any location.

3. I can access WebCT at any time.

4. I can be on WebCT as long as I wish.

5. I feel WebCT is friendly.

6. I feel at ease while using WebCT.

7. I feel comfortable interacting with computers.

8. I feel that WebCT is an important part of this course.

9. I prefer this course be taught by the instructor only.

10. I prefer this course be taught through WebCT only.

11. I prefer this course be taught by Instructor and supported through WebCT.

12. Overall, WebCT helped me in understanding better the course material.

13. Overall, WebCT helped me in learning more the course material.

14. Overall, WebCT helped me in scoring more in the course exams.

$\begin{array}{cccccccccc}1 & 2 & 3 & 4 & 5 & 1 & 2 & 3 & 4 & 5 \\ 1 & 2 & 3 & 4 & 5 & 1 & 2 & 3 & 4 & 5 \\ 1 & 2 & 3 & 4 & 5 & 1 & 2 & 3 & 4 & 5 \\ 1 & 2 & 3 & 4 & 5 & 1 & 2 & 3 & 4 & 5 \\ 1 & 2 & 3 & 4 & 5 & 1 & 2 & 3 & 4 & 5 \\ 1 & 2 & 3 & 4 & 5 & 1 & 2 & 3 & 4 & 5 \\ 1 & 2 & 3 & 4 & 5 & 1 & 2 & 3 & 4 & 5 \\ 1 & 2 & 3 & 4 & 5 & 1 & 2 & 3 & 4 & 5 \\ 1 & 2 & 3 & 4 & 5 & 1 & 2 & 3 & 4 & 5 \\ 1 & 2 & 3 & 4 & 5 & 1 & 2 & 3 & 4 & 5 \\ 1 & 2 & 3 & 4 & 5 & 1 & 2 & 3 & 4 & 5 \\ 1 & 2 & 3 & 4 & 5 & 1 & 2 & 3 & 4 & 5 \\ 1 & 2 & 3 & 4 & 5 & 1 & 2 & 3 & 4 & 5 \\ 1 & 2 & 3 & 4 & 5 & 1 & 2 & 3 & 4 & 5\end{array}$




\section{Biographies}

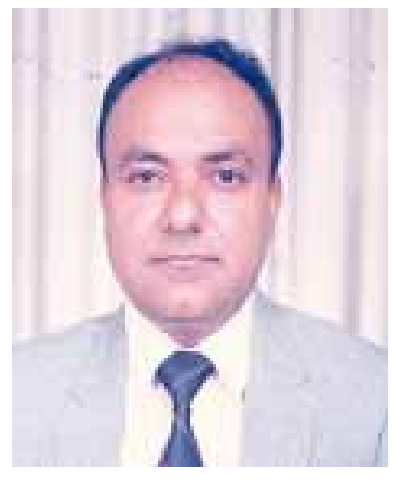

Syed Jafar Naqvi is an Assistant Professor in the Department of Information systems, College of Commerce and Economics, Sultan Qaboos University, Muscat, Sultanate of Oman. He received M.S. from East Texas State University and a Ph.D. from University of Birmingham. His teaching interests include programming languages, Web applications development and e-commerce with research interest in computer education.

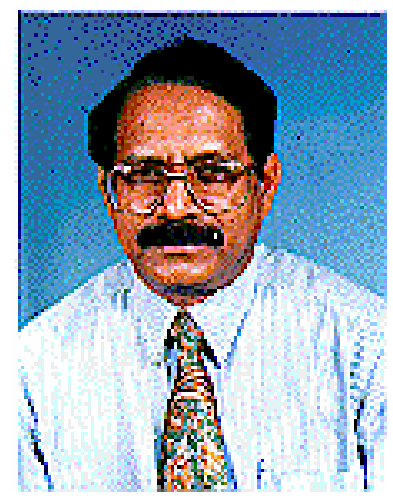

Manzur A. Ajiz is presently working as an Assistant Professor in the Department of Information Systems, College of Commerce and Economics, Sultan Qaboos University, Muscat, Sultanate of Oman. Prior to this he worked at many other prestigious universities and published widely on programming languages, e-commerce and systems development methodologies in national and international journals. 